\title{
Postpartum Acquired Hemophilia Factor VIII Inhibitors and Response to Therapy
}

\section{Doğum Sonrası Kazanılmış Faktör VIII İnhibitörü ve Steroid Tedavisi}

\author{
Volkan Karakuş ${ }^{1}$, Mustafa Çelik², Dilek Soysal ${ }^{1}$, Bahriye Payzın $^{3}$ \\ ${ }^{1}$ Atatürk Research and Training Hospital, Departments of Internal Medicine $1^{\text {st }}$ Division, Izmir, Turkey \\ ${ }^{2}$ Atatürk Research and Training Hospital, Departments of Gastroenterology, Izmir, Turkey \\ ${ }^{3}$ Atatürk Research and Training Hospital, Departments of Hematology, Izmir, Turkey
}

\section{To the Editor,}

Postpartum-acquired hemophilia $\mathrm{A}$ is a rare and potentially severe complication of pregnancy caused by an autoantibody against factor VIII [1]. Acquired factor VIII deficiency is associated with autoimmune conditions, neoplastic diseases, drug hypersensitivity, and pregnancy. A retrospective study analyzed 51 published cases of postpartum factor VIII inhibitors, with regard to the outcome according to treatment [2]. The annual incidence of acquired hemophilia is 0.2-1/1,000,000 and it is difficult to diagnose. Most patients present with major hemorrhage and the mortality rate is about $22 \%$ [3-5].

A 20-year-old female in the postpartum period presented to the hospital with vaginal hemorrhage that had begun $20 \mathrm{~d}$ earlier. Examination of the patient showed that there were no obstetrical or gynecologic pathologies, or acute or chronic diseases causing the hemorrhage. The patient's laboratory data are summarized in the Table 1. The patient's activated partial thromboplastin time (APTT) was $68.4 \mathrm{~s}$. A mixing study using a 50:50 mixture of the patient's plasma and control plasma showed no correction suggesting the presence of an inhibitor. The patient's factor VIII inhibitor level was $2.5 \mathrm{BU} \mathrm{mL}^{-1}$ (normal: $<0.6 \mathrm{BU} \mathrm{mL}^{-}$ $\left.{ }^{1}\right)$. Fresh frozen plasma (174 units), factor VIII (1 unit of VIII: $\mathrm{C} \mathrm{kg}^{-1}$ for every 2 percentage point increase in plasma VIII:C), and recombinant FVIIa (Novo-Seven $90 \mu \mathrm{g} \mathrm{kg}^{-1}$ IV bolus injection, and then the same dose every $3 \mathrm{~h}$ for 1 d) was administered; active bleeding was controlled after $2 \mathrm{~d}$ of the treatment.

Intravenous immunoglobulin (IVIG, $400 \mathrm{mg} \mathrm{kg}^{-1}$ for 5 d) and IV methylprednisolone (60 $\mathrm{mg} \mathrm{d}^{-1}$ for 1 week) was given (as recommended) to eliminate the inhibitor [6]. At follow-up $7 \mathrm{~d}$ after the initiation of treatment the patient was clinically stable with a normal aPTT. Methylprednisolone was initiated at $50 \mathrm{mg} \mathrm{d}^{-1} 8 \mathrm{~d}$ after the start of the initial treatment, and was then gradually tapered and stopped over the course of 6 weeks. The patient was discharged from the hospital 15 days after treatment was initiated. Factor VIII inhibitor was 0.55 BU 4 weeks after delivery. The patient's postpartum hemorrhage was attributed to the presence of acquired factor VIII inhibitor.

Factor VIII inhibitor can be seen in healthy pregnant women without a history of bleeding. Prolonged aPTT and normal PTT is the hallmark of laboratory diagnosis. The objectives of therapy are control of bleeding and elimination of the inhibitor $[5,7]$. Treatment strategies to control active bleeding include the use of factor VIII concentrates, activated prothrombin complex concentrates (anti-inhibitor coagulant complex, Feiba, Autoplex T), and recombinant human factor VIIa $[6,8,9]$. Elimination of factor VIII inhibitor requires the use of immunosuppressive modalities. A prospective randomized trial evaluated the efficacy of prednisone and cyclophosphamide alone, and the combination of both

Address for Correspondence: Volkan KARAKUŞ, M.D., 
Table 1: The patient's laboratory findings.

\begin{tabular}{|c|c|c|}
\hline Laboratory tests & Patient's Value & Normal Value \\
\hline aPTT & $68.4 \mathrm{~s}$ & $25.1-34.7 \mathrm{~s}$ \\
\hline PTT & $11.4 \mathrm{~s}$ & $9.4-14.0 \mathrm{~s}$ \\
\hline International normalized ratio & 0.91 & $0.8-1.2$ \\
\hline Platelet count & $262,000 \mathrm{~mm}^{-3}$ & $130-400 \mathrm{~mm}^{-3}$ \\
\hline Factor VIII rate & $0.55 \%$ & $70 \%-150 \%$ \\
\hline Factor IX rate & $103.9 \%$ & $70 \%-120 \%$ \\
\hline von Willebrand factor & $89.5 \%$ & $50 \%-160 \%$ \\
\hline Factor VIII inhibitor level & $2.5 \mathrm{BU} \mathrm{mL}^{-1}$ & $<0.6 \mathrm{BU} \mathrm{mL}^{-1}$ \\
\hline
\end{tabular}

drugs in 31 non-hemophilic patients with factor VIII antibodies. All patients initially received prednisone (1 $\mathrm{mg} \cdot \mathrm{kg}^{-1} \cdot \mathrm{d}^{-1}$ p.o.) for 3 weeks and the antibody disappeared in 10 of the 31 participants (32\%) during the initial course of prednisone [10]. Another option for the treatment of acquired factor VIII inhibitors is administration of IVIG [11]. Written informed consent was obtained from the patient for publication.

Acquired hemophilia A is a rare and often fatal disorder. Because of difficulties and misdiagnosis delays in diagnosis and treatment are common. As such, whenever acquired hemophilia A-with or without bleeding is suspected immediate consultation with a hemophilia experienced in the management of inhibitors should be initiated.

\section{Conflict of Interest Statement}

The authors of this paper have no conflicts of interest, including specific financial interests, relationships, and/ or affiliations relevant to the subject matter or materials included.

\section{References}

1. Delgado J, Jimenez-Yuste V, Hernandez-Navarro F, Villar A: Acquired haemophilia: Review and meta-analysis focused on therapy and prognostic factors. Br J Haematol 2003; 121 (1): 21-35

2. Hauser I, Schneider B, Lechner K: Post-partum factor VIII inhibitors. A review of the literature with special reference to the value of steroid and immunosuppressive treatment. Thromb Haemost 1995; 73 (1): 1-5
3. Franchini M: Postpartum acquired factor VIII inhibitors. Am J Hematol 2006; 81: 768-773

4. Shobeiri SA, West EC, Kahn MJ, Nolan TE: Postpartum acquired hemophilia (Factor VIII inhibitor): A case report and review of the literature. Obstet Gynecol Surv 2000; 55 (12): 729-737

5. Baudo F, de Cataldo F: Acquired factor VIII inhibitors in pregnancy: Data from the Italian Haemophilia Register relevant to clinical practice.BJOG 2003; 110: 311-314

6. Hay CRM, Brown S, Collins PW, Keeling DM, Liesner R: The diagnosis and management of factor VIII and IX inhibitors:a guideline from the United Kingdom Haemophilia Centre Doctors Organisation. Br J Haematol 2006; 133: 591-605

7. Huang Y W, Saidi P, Philipp C: Acquired factor VIII inhibitors in non-haemophiliac patients: Clinical experience of 15 cases. Haemophilia 2004; 10: 713-721

8. Franchini M, Gandini G, Di Paolantonio T, Mariani G: Acquired hemophilia A: A concise review. Am J Hematol 2005; 80 (1): 55-63

9. Lusher JM: Recombinant factor VIIa (NovoSeven) in the treatment of internal bleeding in patients with factor VIII and IX inhibitors. Haemostasis 1996; 26 (1): 124-130

10. Green D, Rademaker AW, Brit E: A prospective, randomized trial of prednisone and cyclophosphamide in the treatment of patients with factor VIII autoantibodies. Thromb Haemost 1993; 70 (5): 753-757

11. Schwartz RS, Gabriel DA, Aledort LM, Green D, Kessler CM: A prospective study of treatment of acquired (autoimmune) factor VIII inhibitors with high-dose intravenous gammaglobulin. Blood 1995; 86 (2): 797-804 